\title{
EMPREGO DO MÉTODO Z-BUFFER MODIFICADO NA DETECÇÃO DE OCLUSÕES DE EDIFICAÇÕES PARA GERAÇÃO DE ORTOIMAGENS VERDADEIRAS
}

The use of a modified Z-Buffer method in the detection of occluded areas in a generation of true orthoimages

\author{
MARCIS GUALBERTO MENDONÇA JÚNIOR ${ }^{1,2}$ \\ EDSON APARECIDO MITISHITA ${ }^{1}$ \\ ${ }^{1}$ Universidade Federal do Paraná \\ Programa de Pós-graduação em Ciências Geodésicas \\ ${ }^{2}$ Diretoria de Serviço Geográfico \\ marcis@terra.com.br ; mitishita@ufpr.br
}

\begin{abstract}
RESUMO
O uso de modelos digitais de superfície (MDS) aliado a existência de áreas oclusas faz com que, na geração de ortoimagens verdadeiras, ocorra a formação de um fenômeno conhecido como "duplo mapeamento". Para evitá-lo é necessária à detecção das áreas oclusas existentes, e o método mais utilizado na atualidade tem origem na Computação Gráfica, e se denomina Método Z-Buffer. Esse artigo apresenta a implementação de algoritmos para ortorretificação de fotografias aéreas, com emprego do método inverso, e para detecção de áreas oclusas, com base em uma modificação do Z-Buffer, denominada de Método Z-Buffer Modificado. Como áreas de estudo foram utilizadas duas áreas da cidade de Curitiba - PR, que possuíam recobrimento fotogramétrico e MDS disponíveis. Os resultados obtidos possibilitaram identificar o comportamento do Método Z-Buffer Modificado na detecção das áreas oclusas, e como sua principal limitação, denominada de Porção M, influência na supressão dos Duplos Mapeamentos formados durante a geração das ortoimagens verdadeiras.
\end{abstract}

Palavras chave: Ortoimagem Verdadeira; Duplo Mapeamento; Oclusão; Z-Buffer.

\section{ABSTRACT}

"Double mapping" is a phenomenon that occurs when true orthophotos are generated using digital surface models (DSM) in areas with occluded areas. To 
avoid this unwanted effect, the detection of the existing occluded areas becomes a requirement. The most popular solution is called Z-Buffer, a Computer Graphics (CG) method. This article presents the implementation of an algorithm to detect occlusion areas in true orthophoto generation using backward projection, based on a Modified Z-Buffer method. Two areas of Curitiba-PR were used for the study, as both of them were available in photogrammetric flight and MDS forms. The results outlined the behavior of this method and the way its main limitation, the M portion, can influence the suppression of double imaging formed during the generation of true orthoimages.

Keywords: True Orthophoto; Double Mapping; Occlusio; Z-Buffer.

\section{INTRODUÇÃO}

A geração de ortoimagens em ambientes urbanos sofre influência direta da presença, na superfície terrestre, de elementos artificiais (edifícios, pontes, galpões, etc.), que ao serem representados na imagem retificada mantêm a mesma geometria da fotografia aérea original. A causa desse problema é a utilização do modelo digital do terreno (MDT), que contém apenas as informações do terreno, em vez do modelo digital de superfície (MDS), que contém as informações do terreno e dos objetos situados acima dele, tais como, vegetação e edificações em geral.

No entanto, ao se utilizar o MDS como uma fonte de informação na geração das ortoimagens surge outro problema na representação desses objetos, que é a formação de áreas que se repetem na nova imagem. Esse problema é conhecido como Duplo Mapeamento ou, também, como Efeito Fantasma (BRAUN, 2003), e sua causa é a existência de áreas oclusas no terreno, quando vistas a partir do centro perspectivo (CP) da fotografia aérea.

A primeira solução foi apresentada por AMHAR e ECKER (1996), que propuseram uma metodologia para geração de ortoimagens em ambientes urbanos com a utilização de dois modelos isolados, o primeiro representando o terreno e o segundo as edificações em geral. O termo utilizado pelos autores para designar a imagem ortorretificada foi correct orthophoto. Posteriormente, em 1998, no Simpósio da Comissão IV da Sociedade Internacional de Fotogrametria, AMHAR et al. (1998) e SCHICLER e THORPE (1998) utilizaram os termos true orthophoto e true orthophotography, respectivamente, para designar as ortoimagens que corrigiam os erros provenientes do uso do MDS como fonte de informação.

Os principais métodos de ortorretificação de imagens são o Método Direto e o Inverso, que podem ser empregados com a utilização do MDT e do MDS. No entanto, na geração das ortoimagens verdadeiras existe a necessidade de se executar procedimentos complementares visando identificar e corrigir os Duplos Mapeamentos existentes, pela utilização de algoritmos específicos de deteç̧ão de áreas oclusas e de substituição dos pixels repetidos. Esse artigo tem como foco a identificação das áreas oclusas presentes em uma ortoimagem verdadeira.

A Computação Gráfica (CG) é a origem do método de detecção de oclusão 
mais utilizado na geração de ortoimagens verdadeiras, denominado Método ZBuffer (BANG et al., 2007), apesar de sua criação ter sido realizada na década de 1970. Ele é um dos métodos de detecção de visibilidade de superfícies mais simples (FOLEY et al., 2001), estando presente nas principais bibliotecas gráficas disponíveis no mercado, como a OPENGL e a Direct3D (FERGUSON, 2001)). Outro método proveniente da CG que foi adaptado para a geração de ortoimagens verdadeiras é o Ray-tracing, utilizado nos artigos de Machado et al. (2005), e LI et al. (2005). No presente trabalho o método Z-Buffer será analisado somente sob o enfoque da geração de ortoimagens verdadeiras, e não da CG.

Outros pesquisadores sugeriram métodos de deteç̧ão de oclusões mais específicos para aplicação na geração de ortoimagens verdadeiras. Como exemplos têm-se os métodos de BRITO (1997), que propôs uma solução baseada na teoria da probabilidade, VOLOTÃO (2001), que apresentou uma solução baseada na medição de distâncias a partir da semelhança de triângulos, KUZMIN et al. (2004), que utilizaram vetores da base cartográfica existente, projetando-os na fotografia aérea e analisando suas sobreposições, ALBERTZ e WOLF (2004), que propuseram uma solução com base exclusivamente na análise da projeção das sombras das edificações, HABIB et al. (2007), que apresentaram uma solução baseada na análise de ângulos de retas que passam pelo CP, e CHEN et al. (2007), que utilizaram informações de um modelo representativo das edificações e sua projeção em uma imagem orbital.

HABBIB et al. (2007) apresentaram uma série de restrições teóricas sobre o uso do Z-Buffer na geração de ortoimagens verdadeiras, sem que houvesse um aprofundamento em suas análises ou uma comprovação real do problema. Com isso, esse artigo se propõe a analisar a detecção das oclusões, provocadas por edificações de grande porte, presentes em uma ortoimagem verdadeira com a utilização de uma variação do Método Z-Buffer. O método é descrito e são apresentadas suas limitações de emprego. Como mecanismo de trabalho empírico foram selecionadas áreas de pesquisa reais, localizadas na cidade de Curitiba - PR, cujos MDS e recobrimentos fotogramétricos estavam disponíveis.

\section{GERAÇÃO DE ORTOIMAGENS VERDADEIRAS E O DUPLO MAPEAMENTO}

Na atualidade os métodos de geração de ortoimagens mais utilizados são o Método Direto (forward projection) e o Método Inverso (backward projection) (MIKAHIL et al., 2001; SHENG et al., 2003; BANG et al., 2007). Existe ainda outra abordagem, que combina os dois métodos, denominada Método Híbrido (DAL POZ e SANTOS, 1999).

No Método Direto parte-se de um pixel na fotografia aérea (digital), cujas coordenadas fotogramétricas são conhecidas, e determina-se seu correspondente na imagem ortorretificada (Figura 01-A). No processo inverso, parte-se do pixel da ortoimagem, cujas coordenadas cartesianas, geocêntricas ou locais, são conhecidas, 
e determina-se o pixel correspondente na fotografia aérea (Figura 01-B). Em ambos os métodos utiliza-se a Equação de Colinearidade como modelo matemático, e, como não ocorre a correspondência direta entre os pixels da fotografia aérea e da ortoimagem, ou vice-versa, existe a necessidade de utilizar métodos de interpolação para materializar essa correspondência.

Figura 01 - Métodos de Ortorretificação de Imagens.

A-MÉTODO DIRETO

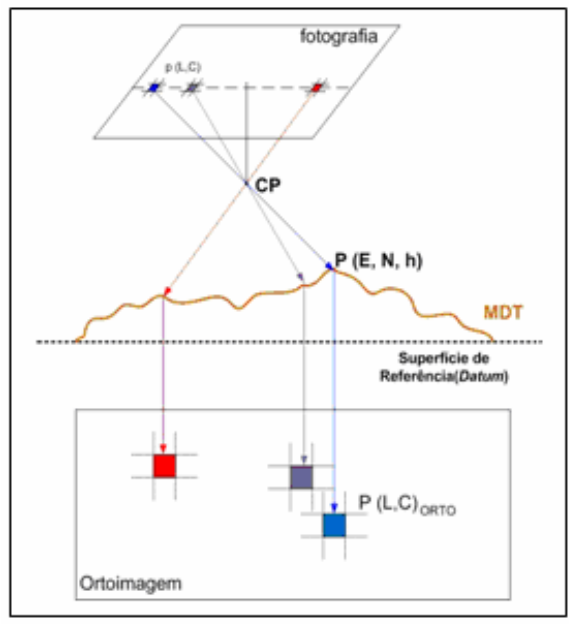

B-MÉTODO INVERSO

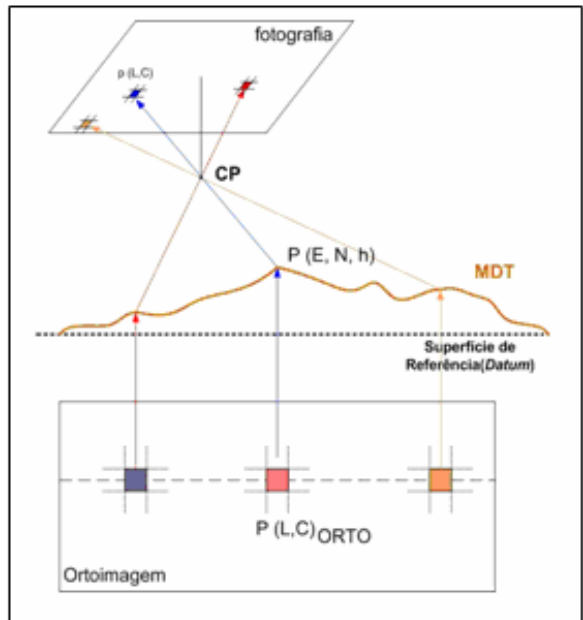

FONTE: MIKHAIL ET AL (2001).

No caso da geração de ortoimagens verdadeiras esses mesmos métodos são aplicados, sendo necessária a aplicação posterior de algoritmos adicionais para a detecção das áreas oclusas e para a substituição dos pixels dessas áreas (MIKHAIL et al., 2001; SHENG et al., 2003; BANG et al., 2007).

Genericamente pode-se definir área oclusa (ou oclusão) como sendo a porção da superfície terrestre não visível, a partir de um ponto de vista, em uma imagem de Sensoriamento Remoto (BRITO, 1997). No caso das fotografias aéreas, pode-se definir área oclusa como sendo a porção do terreno oculta pela projeção dos feixes perspectivos na superfície do objeto oclusor quando da tomada da fotografia aérea, a partir do CP da câmera.

A presença de áreas oclusas nas fotografias aéreas é a maior fonte de incorreções nas ortoimagens verdadeiras (RAU et al., 2000; BRAUN, 2003), e a causa principal de sua ocorrência é a existência de descontinuidades bruscas na superfície terrestre, como, escarpas acentuadas no ambiente rural, e edificações no ambiente urbano, sendo que esta última se torna relevante devido a sua presença nas cidades. 
Quando se aplicam os algoritmos de geração de ortoimagens em ambientes urbanos, com o emprego de MDS, tem-se como consequência da presença das oclusões a formação do Duplo Mapeamento ou Efeito Fantasma (BRAUN, 2003). A Figura 02 apresenta o perfil da tomada de uma fotografia aérea em um terreno que contém duas edificações, com as respectivas áreas oclusas, que ao serem representadas em uma ortoimagem verdadeira provocam o aparecimento do Duplo Mapeamento.

Figura 02 - Área Oculta e Duplo Mapeamento.

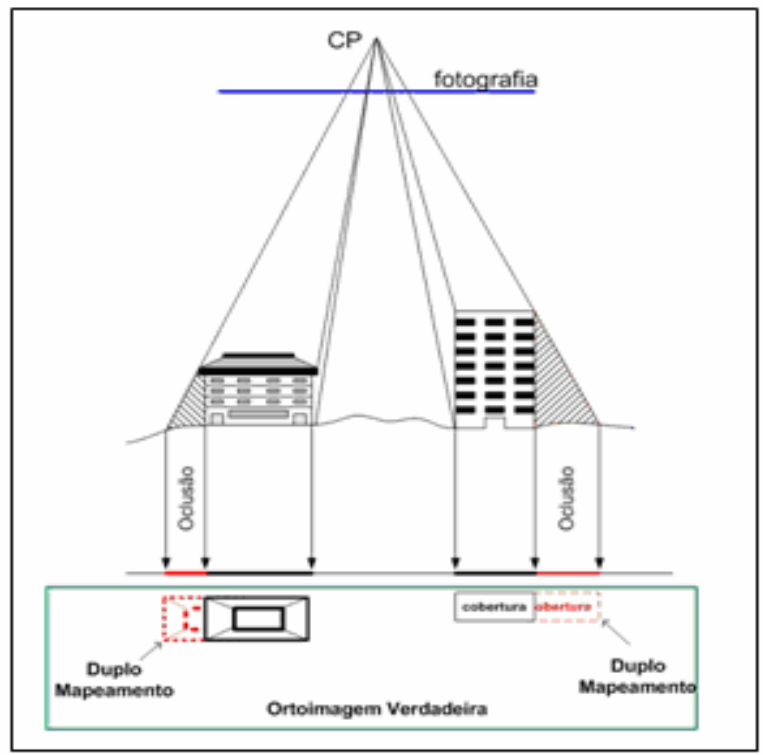

O Duplo Mapeamento é formado a partir da repetição de pixels em locais distintos na ortoimagem verdadeira. Para exemplificar essa ocorrência, é possível verificar na Figura 03 que os pontos $\mathrm{C}$ e $\mathrm{F}$, localizados, respectivamente, na cobertura da edificação e no terreno, são representados pelo mesmo pixel na fotografia aérea. A área oclusa na superfície é representada pelo polígono $\overline{E D G}$, e a lateral visível da edificação pela reta $\overline{A B}$. Ao realizar a geração da ortoimagem verdadeira, essa "competição" de pixels da fotografia aérea faz com que os dois pixels da ortoimagem sejam representados pelo mesmo pixel da fotografia aérea, formando o duplo mapeamento. A lateral da edificação é representada por sua projeção ortogonal, sem que a inclinação presente na fotografia ocorra na ortoimagem verdadeira. A Figura 04 exemplifica o Duplo Mapeamento a partir da representação real de uma edificação em uma ortoimagem verdadeira. 
Figura 03 - Esquema do Duplo Mapeamento (Perfil).

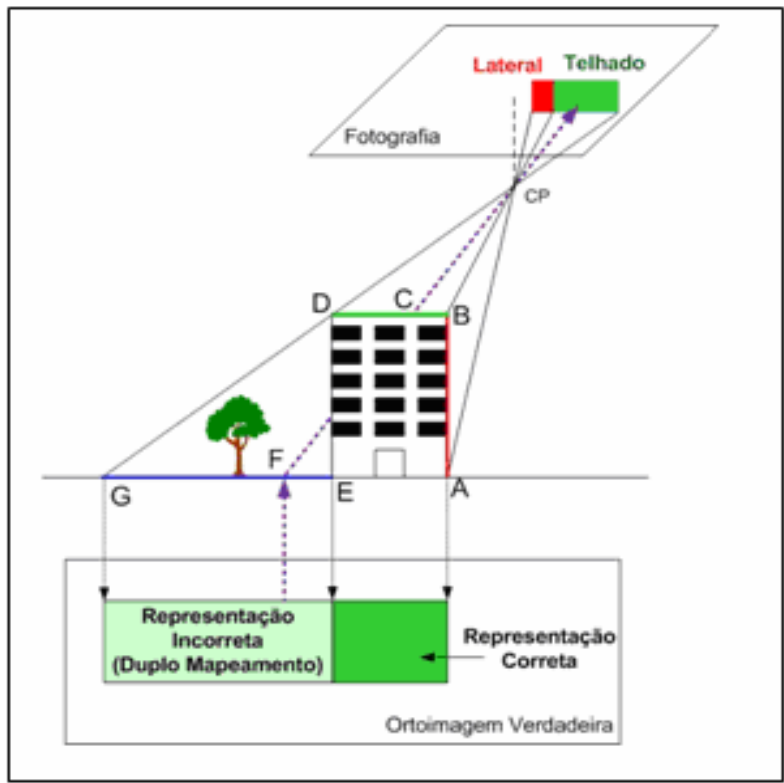

Figura 04 - Ortoimagem Veerdadeira com Duplo Mapeamento.

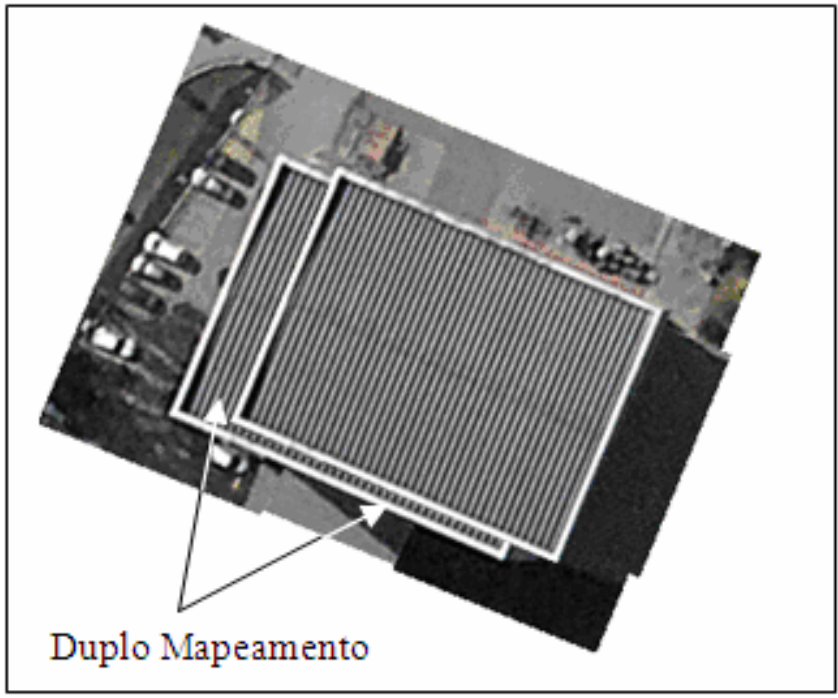

Bol. Ciênc. Geod., sec. Artigos, Curitiba, v. 17, nº 1, p.93-114, jan-mar, 2011. 
A análise das Figuras 03 e 04 permite inferir que, para que a ortoimagem verdadeira seja gerada, é necessário que os pixels das áreas oclusas (duplos mapeamentos) sejam substituídos por outros pixels, provenientes, por exemplo, de outras ortoimagens verdadeiras do mesmo bloco fotogramétrico. SCHICLER e THORPE (1998) foram os primeiros a propor tal solução, sugerindo três fatores a serem considerados para a seleção do pixel substituto: proximidade do nadir de sua fotografia aérea, distância da área oclusa e orientação do pixel em relação a vertical do lugar.

Com isso, verifica-se que a geração de ortoimagens verdadeiras deve conter algoritmos capazes de realizar três tarefas em sequência: ortorretificar imagens (fotografias aéreas), identificar as áreas oclusas e substituir os pixels pertencentes as áreas oclusas detectadas. No presente artigo somente as duas primeiras tarefas serão abordadas.

\section{O MÉTODO Z-BUFFER APLICADO À DETECÇÃO DE OCLUSÕES}

Como já foi mencionado, o algoritmo $Z$ Buffer é um dos mais simples algoritmos de análise de visibilidade de superfícies existentes, o que se deve a simplicidade de seu mecanismo de análise, baseado no fato de que os pontos situados à frente obstruem os situados atrás, provocando uma competição entre dois, ou mais, pontos do terreno pelo mesmo ponto na fotografia aérea (HABIB et al., 2007). Em linhas gerais, o Z-Buffer analisa a visibilidade de porções da superfície terrestre por meio da análise individual de cada um de seus elementos definidores (denominados de groundel - ground element), presentes no modelo representativo dessa superfície (MDT ou MDS).

RAU et al. (2000) apresentam uma estrutura de implementação do Z-Buffer composta por 03 matrizes: Matriz A (Z-Buffer), Matriz B (Frame Buffer) e um Índice de Visibilidade. A Matriz A, com a mesma dimensão da fotografia aérea, armazena as distâncias entre o ponto de vista (no caso, o CP) e os inúmeros groundels da superfície. A Matriz B, também com a mesma dimensão da fotografia aérea, armazena as informações para o caso da troca de visibilidade entre os groundels. O Índice de Visibilidade é uma matriz utilizada para indicar a visibilidade de cada groundel (visível ou não visível).

O processo inicia pela atribuição de valores negativos para todas as células da Matriz A (Z-Buffer). Posteriormente, as coordenadas de suas células são calculadas no sistema fotogramétrico (x,y), e projetadas, com emprego da Equação de Colinearidade, no terreno, determinando as coordenadas do groundel correspondente no sistema cartesiano geocêntrico ou local. De posse desses valores, calculam-se as distâncias entre o groundel e o CP, que são comparadas com a armazenada na Matriz A (Z-Buffer). Se essa distância for maior do que ela, a célula correspondente no Índice de Visibilidade é sinalizada como não visível. Se ocorrer o contrário, o sistema, utilizando a Matriz B (Frame-Buffer), indica a posição correspondente para a troca da sinalização de visibilidade. A Matriz A (Z-Buffer) é 
atualizada com novos valores sempre que um groundel visível é identificado. No fim do processo, o Índice de Visibilidade contém as informações sobre a visibilidade de todos os groundels do modelo.

Para exemplificar a análise da "competição" de pixels utilizada no Z-Buffer serão discutidos alguns aspectos presentes na Figura 05, que contém a perspectiva vertical de uma fotografia aérea e da superfície terrestre composta pelo terreno (plano horizontal), uma edificação e uma árvore (MDS).

Figura 05 - Competição entre Pixels.

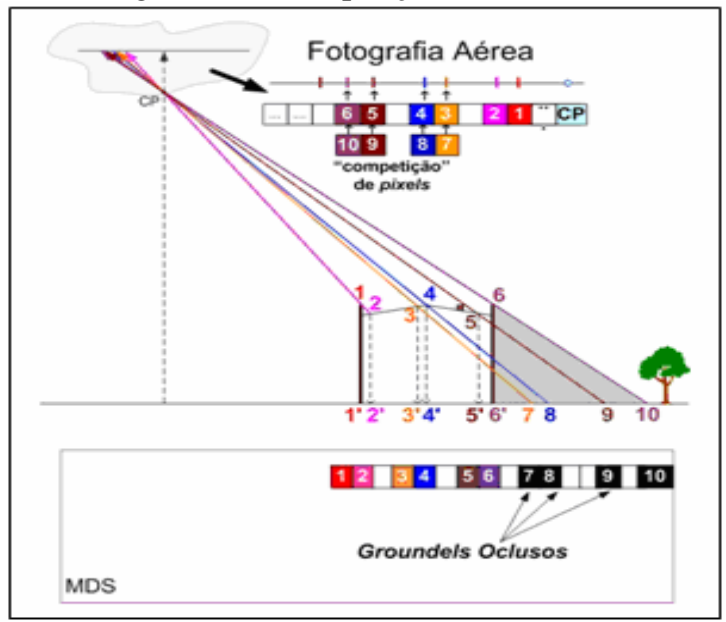

De uma forma geral, é possível verificar que os pares de groundels $(3,7)$; $(4,8)$; $(5,9)$ e $(6,10)$ do MDS, “competem” dentro de cada par, pelo mesmo pixel na fotografia aérea, o que não ocorre no MDS, onde cada groundel possui um espaço de representação específico.

Segundo o critério adotado pelo método Z-Buffer deve-se realizar, para cada par, a análise das distâncias entre o CP e groundels conflitantes. Por exemplo, os groundels 4 e 8 no MDS, respectivamente, competem pelo mesmo pixel na fotografia aérea. Segundo o critério do Z-Buffer, como a distância $\overline{C P-4}$ é menor do que a distância $\overline{C P-8}$, o groundel "4" é classificado como visível (oclusor) e o groundel "8” como não visível (ocluído).

O método Z-Buffer possui uma limitação que é conhecida como Porção M (RAU et al., 2000; RAU et al., 2002; SHENG et al., 2003; HABIB et al., 2007) cuja causa é sua incapacidade de detectar as oclusões provocadas por descontinuidades verticais abruptas existentes na superfície terrestre, como é o caso, por exemplo, das 
componentes verticais de edificações, árvores de grande porte isoladas, escarpas acentuadas etc.

Essa incapacidade advém, principalmente, da estrutura utilizada para representar a superfície ser a malha regular, o que faz com que as descontinuidades verticais abruptas não sejam representadas nos modelos. Essa limitação é uma importante característica quando da geração de imagens verdadeiras em ambientes urbanos devido à elevada presença de edificações de grande porte. A Figura 06 apresenta a vista de perfil de uma edificação e a Porção $\mathrm{M}$ formada por sua componente vertical.

Figura 06 - Porção M.

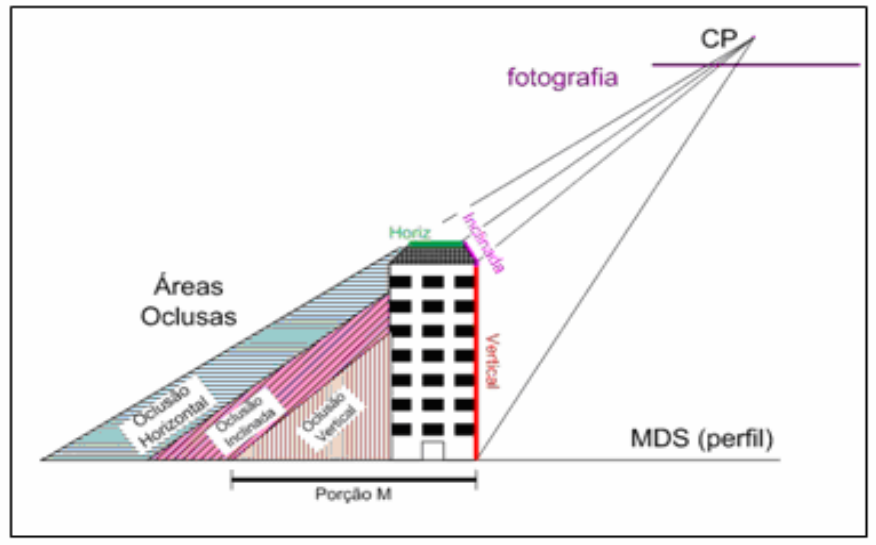

A Porção M é materializada de duas formas no Mapa Índice, sendo a primeira pela separação física entre a edificação e sua oclusão detectada (Figura 07-A), e a segunda pela não identificação da região entre as quinas da edificação e de sua oclusão detectada (Figura 07-B).

Figura 07 - Materialização da Porção M.

A-SEPARACÃO FÍSICA

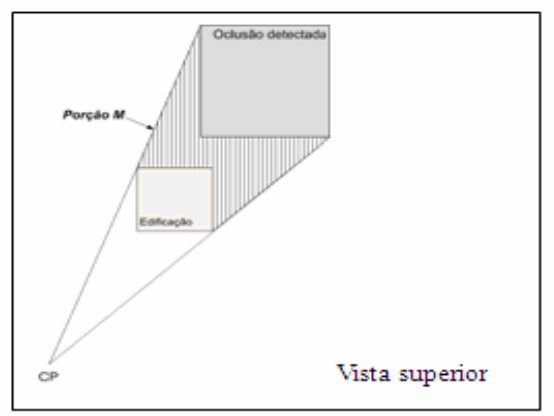

\section{B - QUINA}

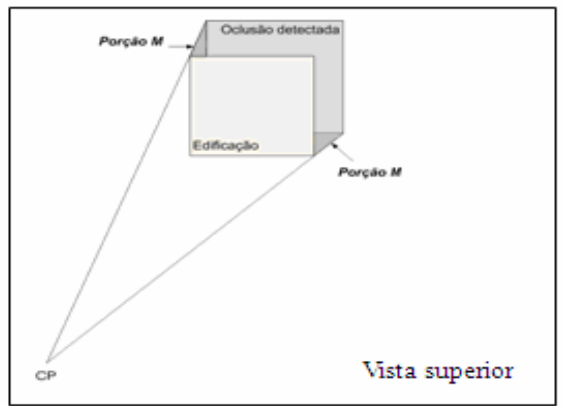




\section{MÉTODO IMPLEMENTADO}

Como o foco do presente artigo é a identificação das áreas oclusas, foram implementados algoritmos para a ortorretificação de fotografias aéreas e para a deteç̧ão das oclusões. O sistema inicialmente ortorretifica a imagem e, posteriormente, identifica os pixels oclusos. Todos os algoritmos foram escritos e implementados pelos autores para serem executados no programa MatLab v5.3, disponível no Laboratório de Fotogrametria do Curso de Pós-graduação em Ciência Geodésicas da Universidade Federal do Paraná (Lab Foto do CPGCG).

A primeira tarefa realizada foi a reamostragem do MDS para que ele e a ortoimagem verdadeira gerada tivessem as mesmas dimensões e resolução geométrica, de forma que cada groundel do MDS e cada pixel da ortoimagem verdadeira representassem as mesmas posições e áreas da superfície terrestre.

O método de ortorretificação de imagens desenvolvido foi baseado no Método Inverso. A sequência de transformações executadas é a apresentada na Figura 08.

Figura o8 - Seqüência de Transformações do Método Inverso.

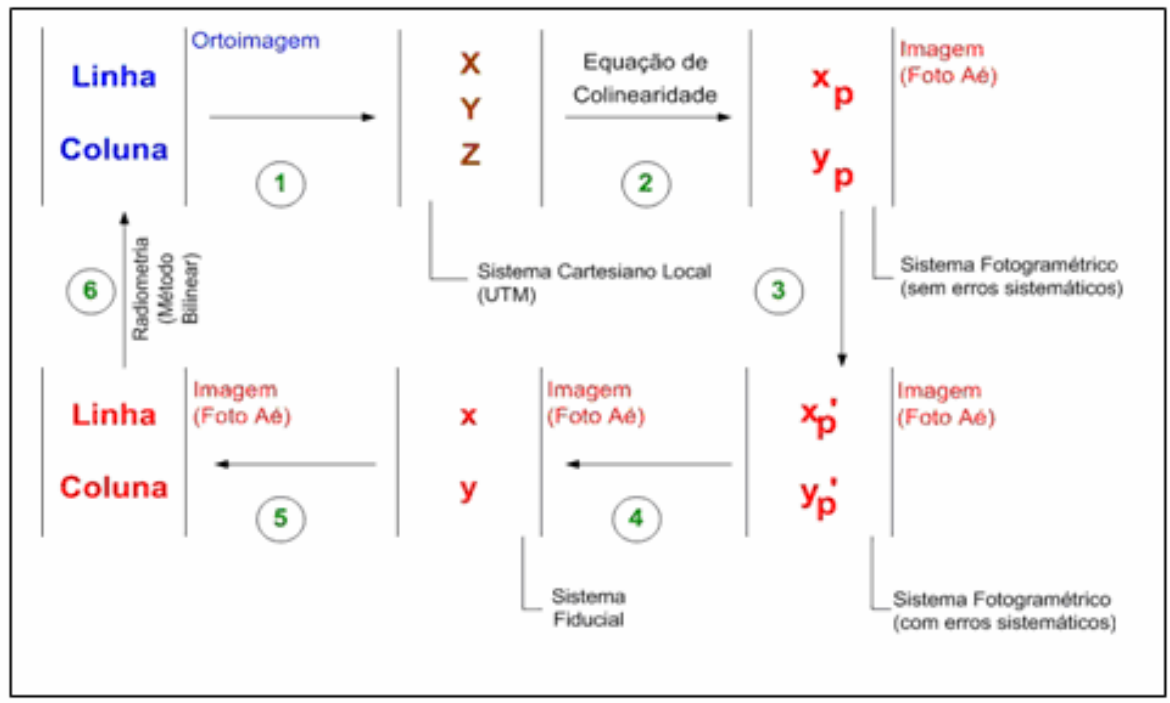

O método de detecção de oclusões utilizado foi o Z-Buffer com algumas modificações. O princípio do método de identificar as "competições” entre pixels foi mantido, e a técnica de identificar quais são os groundels oclusos, pelo emprego de uma matriz de distâncias, foi alterado. A sequência prevista originalmente no ZBuffer se assemelha com o Método Direto (forward projection) de ortorretificação de imagens, pois, ambos partem de informações baseadas na fotografia aérea, que 
são projetadas no MDS ou na ortoimagem.

A implementação realizada baseou-se no Método Inverso ou seja, partiu-se de informações baseadas no MDS que foram projetadas na fotografia aérea. Com isso, o uso da Matriz A foi alterado, mantendo-se as mesmas dimensões da fotografia aérea, mas utilizando-a como um contador de feixes perspectivos que são projetados em cada pixel. A Matriz B, com as mesmas dimensões da fotografia aérea, e o Índice de Visibilidade, com as mesmas dimensões do MDS, permaneceram contendo as informações necessárias para a troca de visibilidade de um groundel e de visibilidade dos groundels do MDS (visível ou não visível), respectivamente.

O método inicia com todos os elementos das Matrizes A e B assumindo o valor zero e os do Índice de Visibilidade sendo iniciados como "visíveis". A seguir, os groundels do MDS são projetados um a um na fotografia aérea, e cada feixe que chega a um pixel na Matriz A altera seu valor, acrescentando uma unidade. Se o valor original desse pixel é "zero", nas mesmas coordenadas (linha, coluna) da Matriz B é inserida a localização do groundel correspondente no MDS. Se os valores são iguais, ou superiores, a "um” na Matriz A, o sistema identifica que está ocorrendo a "competição" entre pixels. Nesse caso a coordenada do groundel recém projetado e a armazenada na Matriz B são recuperadas, e o sistema busca no MDS a altitude desses dois groundels. Nesse ponto ocorre a principal diferença do Método Z-Buffer, que é o critério de identificação de qual pixel é ocluso e qual é o oclusor. Optou-se por utilizar a altitude dos groundels tendo em vista que quando se observa a superfície terrestre de um ponto superior, o ponto mais alto sempre obstrui o mais baixo. Em seguida a localização do groundel oclusor é armazenada na Matriz B, e o groundel ocluso é sinalizado como “não visível” no Índice de Visibilidade. O processo termina quando todos os elementos da MDS são analisados.

Esse mesmo critério de análise da visibilidade foi utilizado por BANG et al. (2007), que renomeou o Método Z-Buffer para Height-Buffer. Como o princípio do método Z-Buffer foi mantido (identificação da "competição" entre pixels), os autores desse artigo acharam por bem não renomeá-lo, visando manter a coerência lógica inicial já estabelecida.

Por fim, os elementos sinalizados como "não visíveis" no Índice de Visibilidade foram projetados na ortoimagem verdadeira com cor específica (amarelo), visando identificar as áreas oclusas detectadas.

\section{EXPERIMENTOS E DISCUSSÕES}

Foram realizados dois experimentos para avaliar os resultados decorrentes da aplicação do Método Z-Buffer Modificado na detecção de áreas oclusas em ortoimagens verdadeiras. Cada experimento foi realizado em uma área da qual existiam recobrimentos aerofotogramétricos, realizados com câmera digital não métrica e LiDAR disponíveis, executados pelo Instituto de Tecnologia para o Desenvolvimento (LACTEC), nos anos de 2004 e 2006, respectivamente, na cidade de Curitiba - PR. 
A câmera digital não métrica utilizada em ambos os recobrimentos aerofotogramétricos foi a Kodak Professional DCS PRO 14n Digital Camera, sendo que para cada recobrimento (2004 e 2006) foi utilizado um conjunto de lentes com focais nominais diferentes (50 mm e $35 \mathrm{~mm}$ ), e GSD (ground sample distance) de $0,205 \mathrm{~m}$ e 0,2218 m, respectivamente. Os parâmetros de orientação interior (IOP) da câmera utilizada em cada recobrimento foram determinados, respectivamente, por SANTOS JÚNIOR (2007) e CORTÊS (2007). Os parâmetros de orientação exterior (EOP) das duas fotografias utilizadas (cada área corresponde a um pequeno trecho de uma fotografia de cada recobrimento aerofotogramétrico) foram determinados por MENDONÇA JÚNIOR (2010), recobrimento 2004, e CORTÊS (2007), recobrimento 2006.

Os levantamentos LiDAR originais das duas áreas foram manipulados pelo LACTEC, de forma a disponibilizar duas malhas irregulares, uma correspondendo ao MDT e outra ao MDS. Essas malhas foram, então, novamente manipuladas por MENDONÇA JÚNIOR (2010), que realizou a reconstrução semiautomática das edificações existentes em ambas as áreas, disponibilizando novos MDT, MDS e modelos digitais de superfície normalizados (MDSn), obtidos a partir da subtração do MDT do MDS. Esses modelos foram utilizados na execução dos experimentos.

A primeira área de pesquisa (Área 01) contém uma edificação, com altura máxima de $11 \mathrm{~m}$, com cobertura formada por diversos planos cujos dados foram levantados nos recobrimentos realizados em 2004. As Figuras 09 e 10 apresentam, respectivamente, o MDSn, obtido a partir da subtração do MDT do MDS, e a fotografia aérea da primeira área de pesquisa. Deve-se notar a geometria da edificação na Figura 10, que possibilita visualizar os elementos de sua lateral.

Figura 09 - MDSn Área 01.

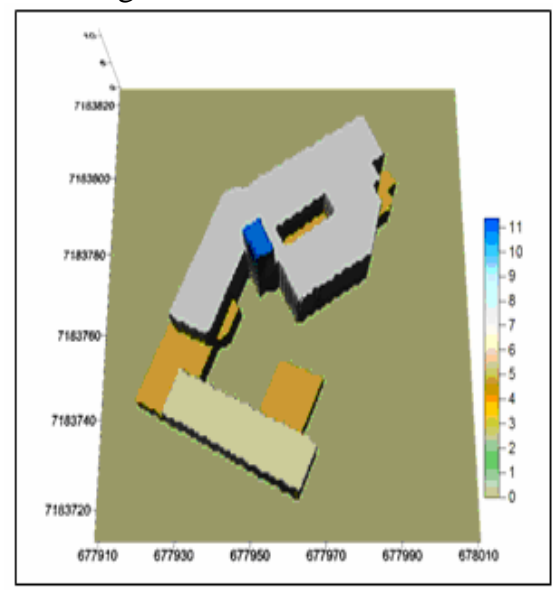

Figura 10 - Foto Aérea - Área 01.

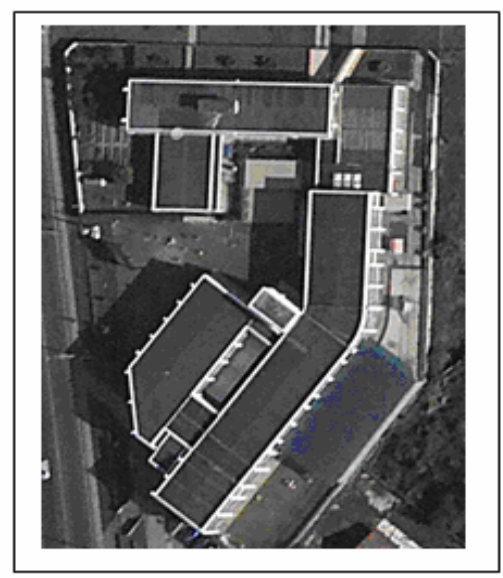

FONTE: MENDOÇA JÚNIOR (2010)

Bol. Ciênc. Geod., sec. Artigos, Curitiba, v. 17, nº 1, p.93-114, jan-mar, 2011. 
A geração da ortoimagem verdadeira foi realizada usando o MDS, o que fez com que o Duplo Mapeamento fosse formado nas áreas oclusas (Figura 11). Note-se que a geometria da edificação é corrigida para a projeção ortogonal, o que faz com que a edificação seja representada corretamente.

Figura 11 - Ortoimagem Verdadeira da Área 01 sem Deteç̧ão de Oclusões.
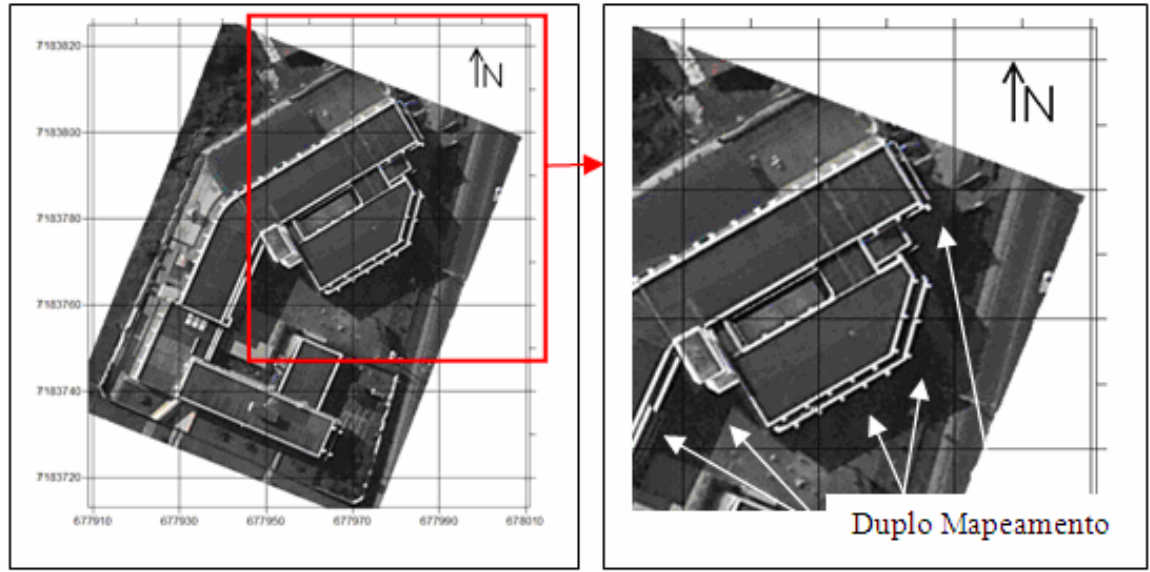

A aplicação do Método Z-Buffer Modificado permitiu que as áreas oclusas fossem identificadas, sendo destacadas na cor amarela na Figura 12. Note-se a coincidência dessas áreas destacadas com o Duplo Mapeamento apresentado na Figura 11.

Figura 12 - Ortoimagem Verdadeira da Área 01 com Detecção de Oclusões.
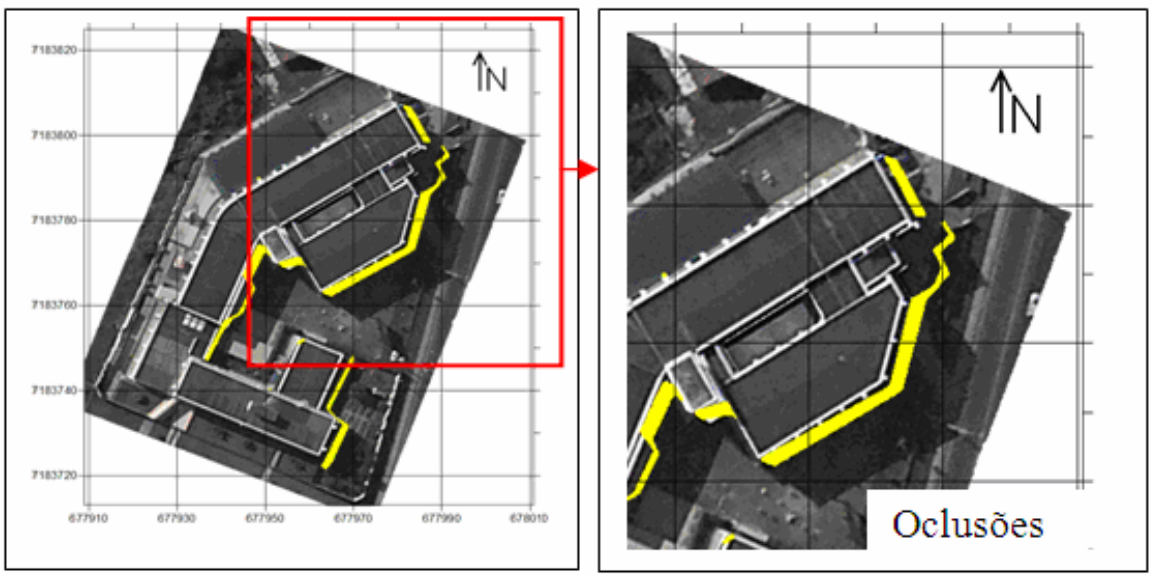

Bol. Ciênc. Geod., sec. Artigos, Curitiba, v. 17, nº 1, p.93-114, jan-mar, 2011. 
A análise visual dos resultados obtidos no primeiro experin ‘ento possibilita verificar que, no geral, os resultados obtidos foram satisfatórios, ter to os duplos mapeamentos, decorrentes da existência de áreas oclusas, sido idéntificados com precisão.

No entanto, os erros existentes no processo tiveram com.) consequência a formação de alguns elementos característicos de ima ortoimagenn convencional na ortoimagem verdadeira. Dentre eles pode-se destacar à presença ce trechos das paredes laterais da edificação (porção A), a manutenção de dìiplo mapeamento na ortoimagem verdadeira (porção B) e o afastamento da oclusão identificada da borda da edificação (porções C e D), conforme indicado, por polígonos na cor vermelha, na Figura 13.

Figura 13 - Ortoimagem Verdadeira da Área 01 com Incorreções.

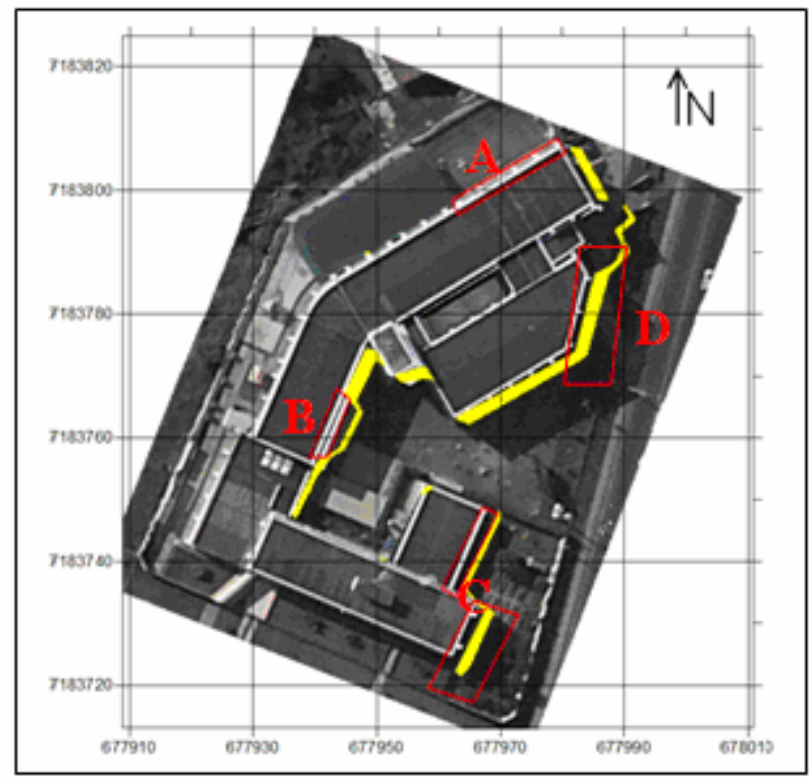

A causa dos erros das porções A, C e D é um pequeno deslocamento do modelo representativo da edificação, que tem como consequência mostrar as janelas na parte da edificação mais próxima do CP e deslocar sua borda na parte mais afastada. Em relação à porção $\mathrm{B}$ o mais provável é que tenha ocorrido um erro na representação da edificação nesse local, pois a manutenção da presença do duplo mapeamento indica que esta porção devia estar oculta (quando vista do CP). Esse erro pode ter se manifestado de duas formas, sendo uma delas a não existência dessa pequena cobertura na edificação, ou a segunda e mais provável, que sua altura 
esteja incorreta no MDS.

A segunda área de pesquisa (Área 02) apresenta duas edificações com alturas máximas pouco superiores a $50 \mathrm{~m}$ e $70 \mathrm{~m}$, respectivamente, cujas informações foram levantadas nos recobrimentos realizados em 2006. Ambas as edificações possuem pequenas construções em suas coberturas, que devem abrigar, provavelmente, as caixas d'água e dos elevadores. As Figuras 14 e 15 apresentam o MDSn da área e sua fotografia aérea, respectivamente.

Figura 14 - MDSn Área 02.

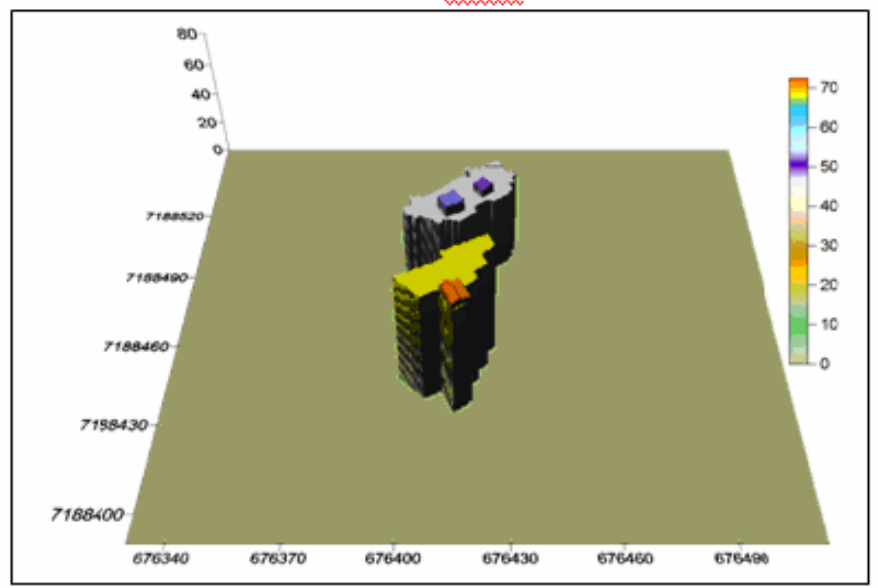

Figura 15 - Foto Aérea - Área 02.

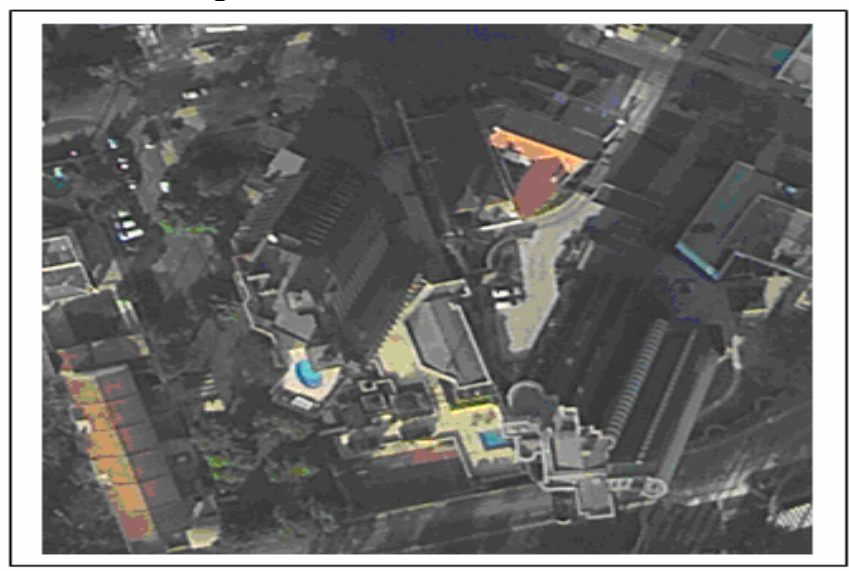

A geração da ortoimagem verdadeira fez com que a geometria das duas 
edificações fosse corrigida. Na Figura 16, que apresenta a ortoimagem verdadeira da Área 02, é possível verificar que as coberturas das edificações são representadas em duas posições diferentes, simultaneamente, o que caracteriza o duplo mapeamento.

Um fato interessante é que, devido às alturas dessas edificações serem elevadas (superior a $50 \mathrm{~m}$ para a edificação mais ao Norte, e superior a $70 \mathrm{~m}$ para edificação mais ao Sul), e também, ao afastamento do CP da fotografia aérea em relação às edificações (o que influencia diretamente o tamanho da área oclusa devido a seu comportamento radial), a ortoimagem verdadeira gerada apresentou problemas, que acabam dificultando, ou impedindo, a identificação visual dos limites das coberturas das próprias edificações.

Figura 16 - Ortoimagem Verdadeira da Área 02 sem Detecção de Oclusões.

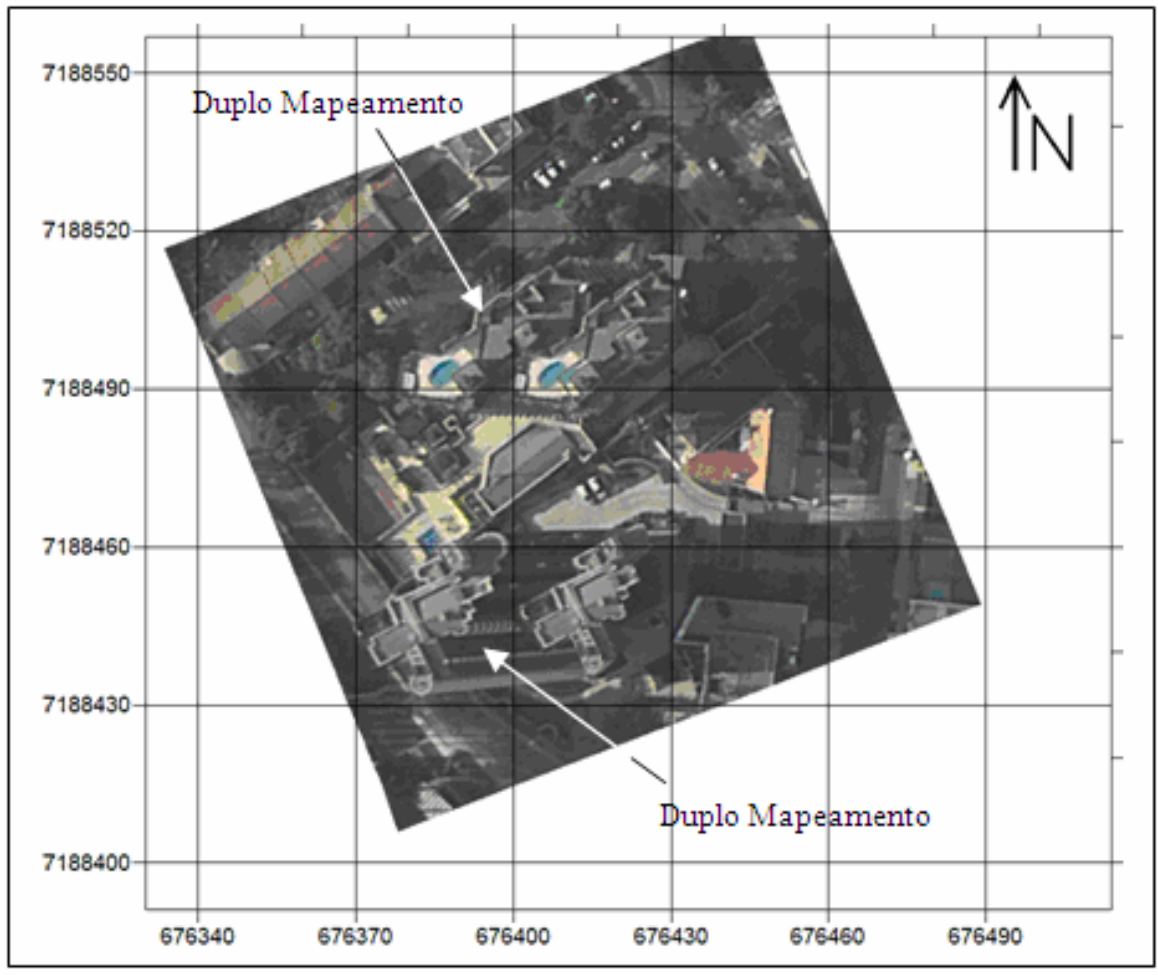

Ao se aplicar o Método Z-Buffer Modificado para detectar as oclusões presentes na Área 02, tem-se como resultado as áreas destacadas na cor amarelo na Figura 17. Sua análise visual, por meio da comparação com a Figura 16, permite 
verificar que os duplos mapeamentos foram identificados com precisão. Note-se, inclusive, que as oclusões provocadas pelas caixas d'água e dos elevadores existentes nas coberturas, foram identificadas corretamente pelo método, o que comprova sua eficiência.

Figura 17 - Ortoimagem Verdadeira da Área 02 com Detecção de Oclusões.

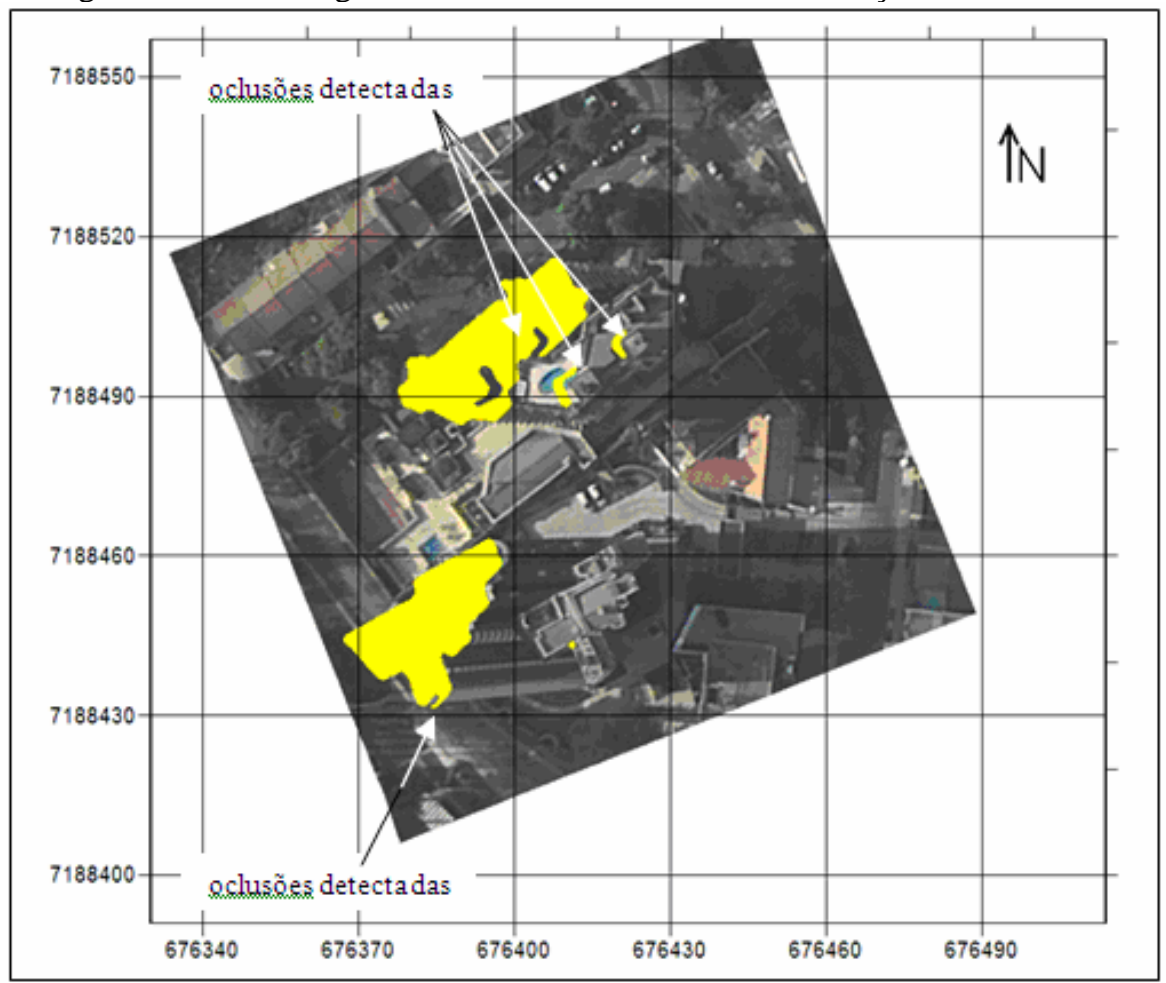

A análise visual da Figura 17 possibilita verificar que existem áreas que não pertencem à cobertura da edificação, nem foram reconhecidas como oclusões (duplos mapeamentos). No total foram identificadas três regiões que deveriam ter sido classificadas como sendo oclusões, e que foram identificadas na Figura 18 (porções A, B e C).

A porção $A$, na cor verde claro, representa a Porção $M$ que provoca a separação física entre a edificação e a oclusão detectada (Figura 07 - A), decorrente da não identificação da oclusão provocada pela componente vertical da edificação mais ao Sul. Como sua altura é elevada (superior a $70 \mathrm{~m}$ ), e o CP da fotografia está afastado horizontalmente dela, tem-se a presença da Porção M. As porções B, na cor 
cinza claro, representam a Porção $M$ decorrente da não identificação da quina das edificações (Figura 07 - B). Nesse caso, devido à altura das edificações, essa porção é preenchida por sua lateral, o que pode gerar dúvidas na interpretação dos limites da própria edificação por um usuário desatento. Deve-se notar que no caso dessa edificação, essas regiões são formadas por construções do tipo "sacadas” ou "varandas", o que dá a impressão da existência "escadas" em sua representação na ortoimagem verdadeira. A porção C, na cor azul, apresenta um problema que não foi descrito em nenhum dos artigos, ou livros, consultados sobre o assunto. Ela representa um "falso positivo", ou seja, a identificação de uma área oclusa como sendo não oclusa (visível). Sua causa são os componentes verticais presentes nas pequenas construções existentes na cobertura da edificação, que acabam provocando o surgimento de pequenas Porções $\mathrm{M}$ dentro do duplo mapeamento, ou de outras Porções M. Esse problema específico é mais uma forma de materializar a existência da Porção M, sendo denominada de Falso-positivo.

Figura 18 - Porção M da Ortoimagem Verdadeira da Área 02.

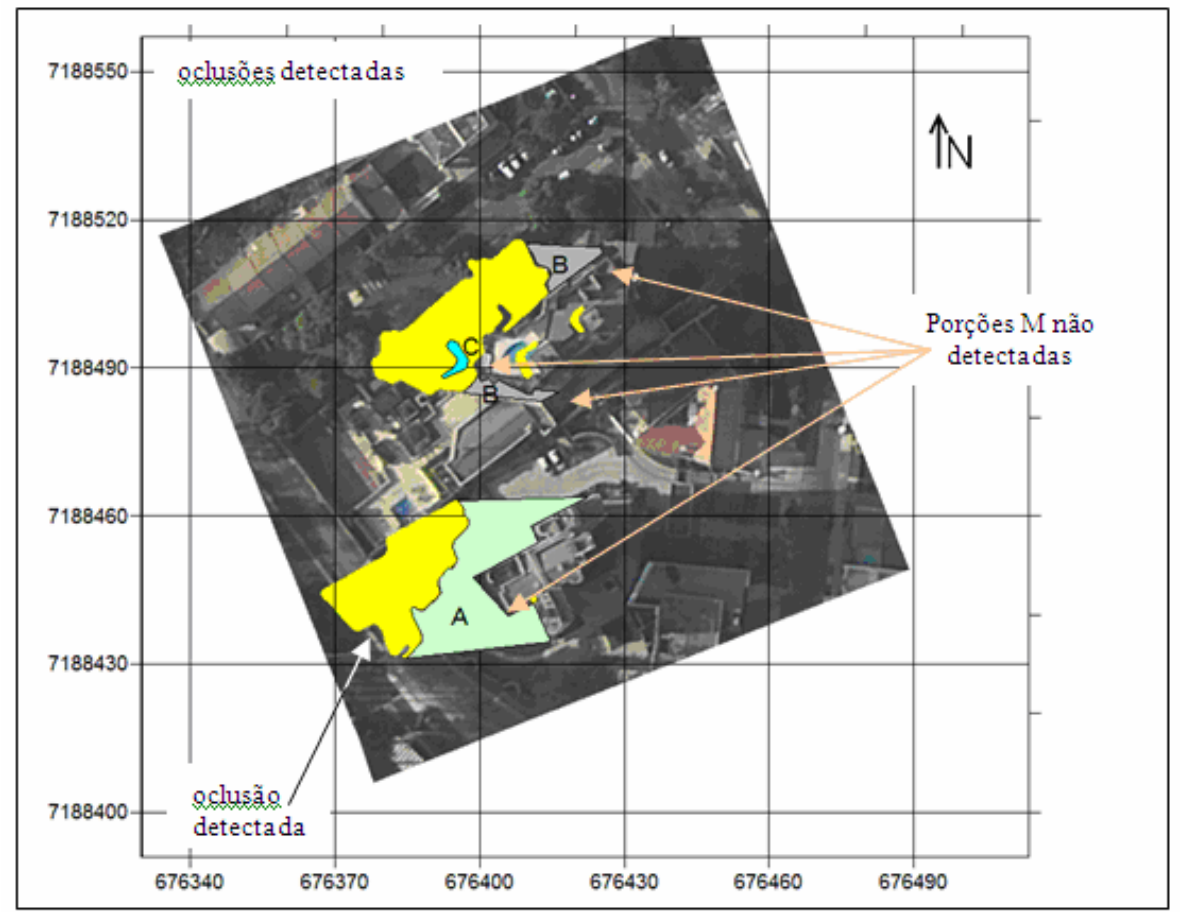

\section{CONCLUSÕES E RECOMENDAÇÕES}

Este artigo se propôs a analisar o comportamento do Método Z-Buffer na 
detecção de oclusões durante a geração de ortoimagens verdadeiras. Foram realizadas revisões sobre os métodos de geração de ortoimagens (direto e inverso) e sobre o método de detecção de oclusões Z-Buffer aplicado à geração de ortoimagens verdadeiras. A seguir, o método implementado, formado pela aplicação do método inverso de ortorretificação de fotografias aéreas, seguida pela aplicação do Método Z-Buffer Modificado para identificação das áreas oclusas, foi apresentado. Por fim, foram descritos os experimentos realizados, com respectivas discussões decorrentes, que servem de base para as conclusões aqui apresentadas.

Verificou-se que a representação de áreas oclusas nas ortoimagens verdadeiras provoca o surgimento de problemas na imagem retificada, sendo possível obter as seguintes conclusões:

- A ocorrência de áreas oclusas na superfície terrestre é função da posição de uma edificação em relação ao CP da fotografia aérea (ou ao ponto de vista do observador), de sua altura e de sua forma;

- As áreas de oclusão têm comportamento radial, quando representadas nas ortoimagens verdadeiras;

- A precisão das edificações presentes no MDS tem influência direta na precisão das ortoimagens geradas, influenciando na manutenção da visualização das laterais das edificações na ortoimagem verdadeira e na identificação dos duplos mapeamentos existentes;

- A presença do duplo mapeamento e da porção M em uma ortoimagem verdadeira é consequência direta da existência de áreas oclusas, havendo, entre eles, uma relação direta de causa e efeito;

- A não detecção da porção M pode fazer com que as partes laterais das edificações sejam visualizadas na ortoimagem verdadeira, podendo gerar dificuldades, ou até mesmo impedir, a correta percepção da forma da própria edificação pelo observador; e

- O Método Z-Buffer Modificado não é capaz de identificar as porções M existentes na ortoimagem verdadeira, mas identifica com precisão os duplos mapeamentos existentes.

Como contribuição pode-se citar a identificação da porção $\mathrm{M}$, materializada pela detecção "Falso Positivo", que tem origem nas componentes verticais de construções presentes nas coberturas das edificações.

Do estudo realizado pode-se recomendar que a utilização do Método Z-Buffer Modificado em áreas que contenham edificações de grande porte deve ser evitada, ou complementada por algoritmos que consigam eliminar, ou minimizar, suas falhas. RAU et al. (2000) apresentou uma solução para a porção M materializada pela separação física, que consiste em determinar a altura da edificação e projetá-la no plano horizontal, sinalizando diretamente que esses groundels são todos oclusos.

Essa não parece ser uma solução ótima, pois impõe algumas suposições (que a oclusão terá sempre, no mínimo, a dimensão da altura da edificação). Uma proposta de solução para esses problemas deve envolver o MDS e o MDT de forma conjunta, 
aproveitando algumas oportunidades que a diferença de altitudes pode fornecer, como, por exemplo, a identificação direta das oclusões existentes na base das edificações, e formação de porções $M$ interiores a áreas oclusas detectadas pelo Método Z-Buffer Modificado. O que se pretende é a identificação direta dos duplos mapeamentos e das materializações da Porção $\mathbf{M}$, incluindo as provocadas pelas construções presentes nas coberturas das edificações.

\section{REFERÊNCIAS BIBLIOGRÁFICAS}

ALBERTZ, J.; WOLF, B., Generating True Orthoimages without a 3D Surface Model. The International Archives of Photogrammetry and Remote Sensing. 2004. v.35 (3). pp. 693-698.

AMHAR, FAHMI; ECKER, ROBERT. An Integrated Solution for the Problems of 3D Man-made Objects in Digital Orthophotos. The International Archives of Photogrammetry and Remote Sensing. 1996.v. 31 (B4).

AMHAR, F.; JANSA, JOSEF; RIES, CHRISTINE. The Generation of True Orthophotos using a 3D Building Model in Conjunction with a Conventional DTM. The International Archives of Photogrammetry and Remote Sensing. 1998. v. 32 (4).

BANG, K. I.; HABIB, AYMAN F.; SHIN, S. W.; KIM, K. O. Comparative Analysis of Alternative Methodologies for True Ortho-photo Generation from High Resolution Satelliite Imagery. In: ASPRS ANNUAL 2007, 2007, Tampa. Proceedings. Disponível em: http://www.ssmatics.com/TrueOrthophotoGenerati on_ASPRS_07ve.pdf. Acesso em Ago 2007.

BRAUN, JOSEF. Aspects on True-Orthophoto Production. In: PHOTOGRAMMETRIC WEEK'03. 2003. Stuttgart: Herbert Wichmann Verlag. Anais. Disponível: www.ifp.uni-stuttgart.de/publications/ phowo03/braun.pdf. Acesso em Ago 2007.

BRITO, JORGE LUÍS NUNES E., Precision os Digital Orthoimages: Assessment and Application to the Oclusion Detection Problem. Columbus. EUA. 1997. Tese (PhD Thesis). The Ohio State University.

CHEN, LIANG-CHIEN; TEO, TEE-ANN; WEN, JEN-YU; RAU, JIANN-YEOU. Occlusion-Compensated True Orthorectification For High-Resolution Satellite Images. The Photogrammetric Record. 2007. v. 22 (117). pp 2-113.

CÔRTES, JOÃO BATISTA RAMOS. Integração de Imagens Digitais com Dados Lidar Empregando Pontos de Apoio Pré-Sinalizados e Fototriangulação. Curitiba. 2007. Relatório de Seminário II (Curso de Pós-graduação em Ciências Geodésicas). Universidade Federal do Paraná (não-publicado).

DAL POZ, ALUIR P.; SANTOS, DANIEL R. Automação do Processo de Orientação Absoluta Metodologia Híbrida. In: XIX CONGRESSO BRASILEIRO DE CARTOGRAFIA E XVII SIMPÓSIO INTERNACIONAL DE FOTOGRAMETRIA. Recife: CBC. Anais do XIX Congresso Brasileiro de Cartografia. 1999. 1 CD-ROM. 
FERGUSON, R. STUART. Pratical Algoritms for 3D Computer Graphics. Natik. A. K. Peters. 2001. 539 p.

FOLEY, JAMES D.; VAN DAM, ANDRIES; STEVEN K., FEINER; HUGHES, JOHN F. Computer Graphics: Principles and pratice. $2^{\text {nd }}$ ed. Boston. 2001. Addison-Wesley. 1175 p.

HABIB, AYMAN F.; KIM, EUI-MYOUNG; KIM, CHANG-JAE. New Methodologies for True Orthophoto Generation. Photogrammetric Engineering \& Remote Sensing. 2007. v. 73(1). pp 025-036.

KUZMIN, P.; KORYTNIK, SERGEY A.; LONG, ORRIN. Polygon-Based True Orthophoto Generation. XX $X^{\text {th }}$ ISPRS Congress Proceedings, 12-23 Julho. Istambul (Turquia). 2004. pp 529-531.

LI, Y.; GONG P.; SASAGAWA T. Integrated Shadow Removal Based on Photogrammetry and Image Analysis. International Journal of Remote Sensing . 2005. v. 26 (18). pp 3911-3929

MACHADO, ÁLVARO; MITISHITA, EDSON A.; DELARA, ROOSEVELT. Algoritmo para Deteç̧ão Automática de Oclusões na Geração de True Ortofoto. Série em Ciências Geodésicas. Curitiba. 2005. v.5. pp 219-228.

MENDONÇA JÚNIOR, MARCIS GUALBERTO. Reconstrução de Edificações para Geração de Ortoimagens Verdadeiras com Emprego de Dados LIDAR. Curitiba. 2010. Tese (Doutorado em Ciências Geodésicas). Universidade Federal do Paraná.

MIKHAIL, EDWARD M.; BETHEL, JAMES S.; McGLONE, J. CHRIS. Introduction to Modern Photogrammetry. Nova Iorque. 2001. John Wiley \& Sons, Inc. 479 p.

RAU, JIANN-YEOU; CHEN, NAI-YU; CHEN, LIANG-CHIEN. Hidden Compensation and Shadow Enhacement for True Orthophoto Generation. In: ASIAN CONFERENCE ON REMOTE SENSING 2000. Proceedings. 2000. Disponível em: http://www.gisdevelopment.net/aars/acrs/2000/ts4/ digi0003.asp . Acesso em Ago 2006.

RAU, JIANN-YEOU; CHEN, NAI-YU; CHEN, LIANG-CHIEN. True Orthophoto Generation of Built-Up areas Using Multi-View Images. Photogrammetric Engineering \& Remote Sensing. v. 68 (6). pp 581-588. 2002.

SANTOS JÚNIOR, ROOSEVELT DELARA. Extração Automática de Pontos de Apoio para Integração de Imagens Aéreas Digitais e Dados de Perfilamento LASER Aerotransportado. Curitiba. 2007. Tese (Doutorado em Ciências Geodésicas). Universidade Federal do Paraná.

SCHICKLER, WOLFGANG; THORPE, ANTHONY.Operational Procedure for Automatic True Orthophoto Generation. International Archives of Photogrammetric and Remote Sensing. 1998. v. 32 (4). pp 527-532.

SHENG, Y.; GONG, P.; BIGING, G. S. True Orthoimage Production for Forested Areas from Large-scale Aerial Photographs. Photogrammetric Engineering \& Remote Sensing. 2003. v. 69(3). pp 259-266. 
VOLOTÃO, CARLOS FREDERICO DE SÁ. Geração de Ortoimagens para Aplicações Urbanas: Desenvolvimento das Equações e Protótipo Experimental. São José dos Campos. 2001. Dissertação. Instituto Nacional de Pesquisas Espaciais.

(Recebido em dezembro de 2009. Aceito em março de 2011) 